\title{
VENTURE CAPITAL AND PRIVATE EQUITY INVESTMENT IN THE Czech Republic
}

\author{
Božena Kadeřábková*1, Petr Ptáček ${ }^{2}$ \\ ${ }^{1}$ University of Economics in Prague, Faculty of Economics, Nam. W. Churchilla 4, 13067 Prague, Czech \\ Republic, bozena.kaderabkova@vse.cz \\ ${ }^{2}$ Ministry of Industry and Trade, Na Frantisku 32, 11015 Prague, Czech Republic
}

\begin{abstract}
The paper analyses venture capital (VC) and private equity (PE) investment activity in the Czech Republic. Our earlier research has shown the development and comparison of Czech and European private equity and venture capital markets in 2007-2012 or 2007-2013 respectively. The aim of this paper is to enhance the time line with the 2014 and 2015 data and find out the differences in market development trends (if any).
\end{abstract}

\section{Keywords}

Venture capital; asset management; private equity; financial markets; market failure; government failure

\section{JEL Classification}

G24

DOI: https://doi.org/10.14311/bit.2017.02.01

Editorial information: journal Business \& IT, ISSN 2570-7434, CreativeCommons license (c) (1) published by CTU in Prague, 2017, http://bit.fsv.cvut.cz/ 


\section{Introduction}

Our earlier research has shown the development and comparison of Czech and European private equity and venture capital markets in 2007-2012 or 2007-2013 respectively. The aim of this paper is to enhance the time line with the 2014 and 2015 data and find out the differences in market development trends (if any).

Theoretical background focuses on definitions connected with venture capital and private equity investing. Results describe the main features of the Czech private equity and venture capital market in relation to the European benchmark with the enhanced data time line using the same methodology as in the previous research. Conclusions concentrate on the latest trends in compare to earlier 2007-2013 data research.

\section{Theoretical background of venture capital and private equity}

Despite its relative importance in terms of ability to help start-ups develop in multinational companies and specific differences from other sources of capital, there is still insufficient background of theoretical economics in the field of venture capital. Despite there have been many attempts to describe the processes of venture capital, the terminology is still not unified.

The researched literature always considers Venture Capital as an asset class, mainly as a subset of Private Equity. But, sometimes is Venture Capital perceived also as a synonym to Private Equity. Generally, the literature shows that there exist at least two stages of venture capital - early stage investments in start-up businesses and later stage investments in developing companies.

Private equity means generally investing capital in unquoted businesses, unlisted on public markets. However, private equity refers to the source of equity funds being on private markets, private equity may be used to invest also in listed shares, including taking over publicly listed companies, and delisting them.

The term Risk Capital is often used as homonym to Venture Capital, but not always. For instance, Merton and Perold (1993) define risk capital as "the smallest amount that can be invested to insure the value of the firm's net assets against a loss in value relative to the risk-free investment of those net assets" (p. 17). This definition is very different and is related to risk management in financial institutions.

Due to Invest Europe (the European VC and PE association), venture capital has two stages - early stage and later-stage. EVCA (2007) distinguishes venture capital as "a subset of PE, refers to equity investments made for the launch, early development or expansion of a business" (p. 6). However, the growth segment is not included, as EVCA (2012) refers to expansion of "relatively mature or developed companies" (p. 40). But, to make it even more complicated, "additionally, most investments made by buyout funds into venture stages would be defined as growth capital" (p. 40). This example shows how challenging it is to distinguish individual stages of PE/VC in practice.

The venture capital and private equity processes are commonly aggregated into three main market activity indicator groups: fundraising activity, investment activity and divestment activity. We will work mainly with fundraising and investment amounts in monetary terms per period of time. 


\section{Venture capital and private equity development in the Czech Republic in compare to Europe}

The investment activity of private equity (PE) and venture capital (VC) in the Czech Republic was observing an upward trend in 2007-2009, decreasing in 2010-2012 with recovery in 2013-2014 and sharp decline in 2015. However, strong expectations have been pronounced by the local market representatives for 2016.

As the overall number of investment is very limited and varies between 10 to 20 in the whole private equity industry in the Czech Republic, the investment activity is influenced by appearance of several larger investments, as depicted below in Table 1.

Table 1. Investment amounts and number of invested companies in VC and PE segments, Czech Republic and Europe, 2007-2015 totals

\begin{tabular}{|c|c|c|c|c|c|c|c|c|}
\hline & \multicolumn{4}{|c|}{ Czech Republic } & \multicolumn{4}{|c|}{ Europe } \\
\hline & $\begin{array}{c}\text { Total } \\
\text { investment }\end{array}$ & $\begin{array}{l}\% \text { of } \\
\text { total }\end{array}$ & $\begin{array}{l}\text { No. of } \\
\text { invested } \\
\text { companies }\end{array}$ & $\begin{array}{c}\% \text { of } \\
\text { invested } \\
\text { companies }\end{array}$ & $\begin{array}{c}\text { Total } \\
\text { investment }\end{array}$ & $\begin{array}{l}\% \text { of } \\
\text { total }\end{array}$ & $\begin{array}{l}\text { No. of } \\
\text { invested } \\
\text { companies }\end{array}$ & $\begin{array}{r}\% 0 \\
\text { invesi } \\
\text { compa }\end{array}$ \\
\hline Seed & 816 & $0,03 \%$ & 3 & $2,14 \%$ & 1347229 & $0,34 \%$ & 3855 & 8,; \\
\hline Start-up & 22298 & $0,77 \%$ & 18 & $12,86 \%$ & 17867673 & $4,51 \%$ & 15831 & 34, \\
\hline $\begin{array}{l}\text { Early- } \\
\text { stage }\end{array}$ & 23113 & $0,80 \%$ & 21 & $15,00 \%$ & 19214902 & $4,85 \%$ & 19686 & 42; \\
\hline $\begin{array}{l}\text { Later- } \\
\text { stage }\end{array}$ & 89969 & $3,12 \%$ & 25 & $17,86 \%$ & 18316146 & $4,63 \%$ & 9209 & 19, \\
\hline Total VC & 113082 & $3,92 \%$ & 46 & $32,86 \%$ & 37531048 & $9,48 \%$ & 28253 & $61 ;$ \\
\hline $\begin{array}{l}\text { Other PE } \\
\text { (Buyouts } \\
\text { etc.) }\end{array}$ & 2771711 & $96,08 \%$ & 94 & $67,14 \%$ & 358478308 & $90,52 \%$ & 17808 & 38, \\
\hline Total & 2884793 & $100,00 \%$ & 140 & $100,00 \%$ & 396009356 & $100 \%$ & 46061 & 100, \\
\hline
\end{tabular}

Source: Own adjustment of EVCA and Invest Europe data

The seed stage investments are almost missing, the first one since 2007 has been made in 2013 amounting only at EUR 515 000, other two investments worth together of EUR 500,000 occurred in 2015. We will see if any change will come in this segment in the coming years, as new venture capital fund Credo Ventures II has been put in place with expected EUR 40 mil. for investments starting just at EUR 50,000. However, the range of the fund is in fact multistage, as the maximum ticket is EUR 6 mil. The planned portfolio is encouraging with target $50 \%$ share of seed stage investments on the venture capital firm total assets under management (currently EUR 58 million).

Start-up investments varied between 0-4 yearly over the whole period 2007-2015 with EUR 22,3 mil. total investments made (but more than EUR 13 million, or 59\%, within a single year 2010). The years 2014-2015 showed relatively stable development with 4, resp. 3 investments made totaling between EUR 1.3-3.0 mil. Credo Ventures II fund should also ensure new investments in near future. Nevertheless, the performance in this segment is still very poor in compare to European figures, as for seed stage investments as well.

However, in seed and start-up stages, there are also existing investments out of official statistics as business angles operate in this field in the Czech Republic almost without being organized in syndicates or networks. 
Later stage venture capital was developing quite hopefully until 2010 with 4 to 5 new investments in a year. Since then, its investment activity has been diminishing to only $3 \%$ of 2009 values in 2013 and almost no value of new investments in 2015.

Overall venture capital investment activity including seed, start-up (together marked as early stage) and later stage investments was very weak and became almost invisible over 2012-2015. Other private equity investments, make out $96 \%$ of all PE and VC investments in the Czech Republic. Most capital has been invested in buyouts (67\% of total PE and VC investment) and growth capital (19\%). Over 2014-2015, the position of buyouts has been still slightly advancing. Rescue, turnaround and replacement capital have been rather rare over 2007-2013 and no new investments in 2014-2015. However, no permanent or systematic changes in the sensitivity to market returns in relation to risk premiums have been generally detected in the Czech financial market after financial crisis, the private equity fundraising activity indicators (including venture capital) show less willingness to allocate capital to private equity and venture capital funds from investors.

Even though - the situation may be getting better in the coming years. The main Czech PE firm Genesis has introduced new fund GPEF III in 2015 with EUR 60 mil. available for investments. The investors' list has changed in compare to previous funds of this PE firm. They are no more dependent on international financial institutions (such as EBRD) as they attracted also domestic financial investors including Česká spořitelna, major retail bank or Investiční společnost Komerční banky, investment company of other Czech retail bank or Kooperativa, an insurance company. This is a very promising signal that could help further develop PE market in the coming years. The market needs more domestic investors and also more domestic VC and PE firms.

Therefore, however the data presented in Chart 1 below does not seem very encouraging, the CVCA market players are rather optimistic as regards its further development, mainly due to growth expectations based on previous good performance in 2014-2015. These may or not may be fulfilled as the Czech economy has been performing almost in full employment mode in 2016 and thus the potential product is either very close or has been already exceeded. Expansionary monetary policy has been in place since 2013 and in June 2016, the Czech National Bank decided to limit terms of new mortgages as the $20 \%$ year-on-year increase in housing prices may be the first signal of overheating of the Czech economy.

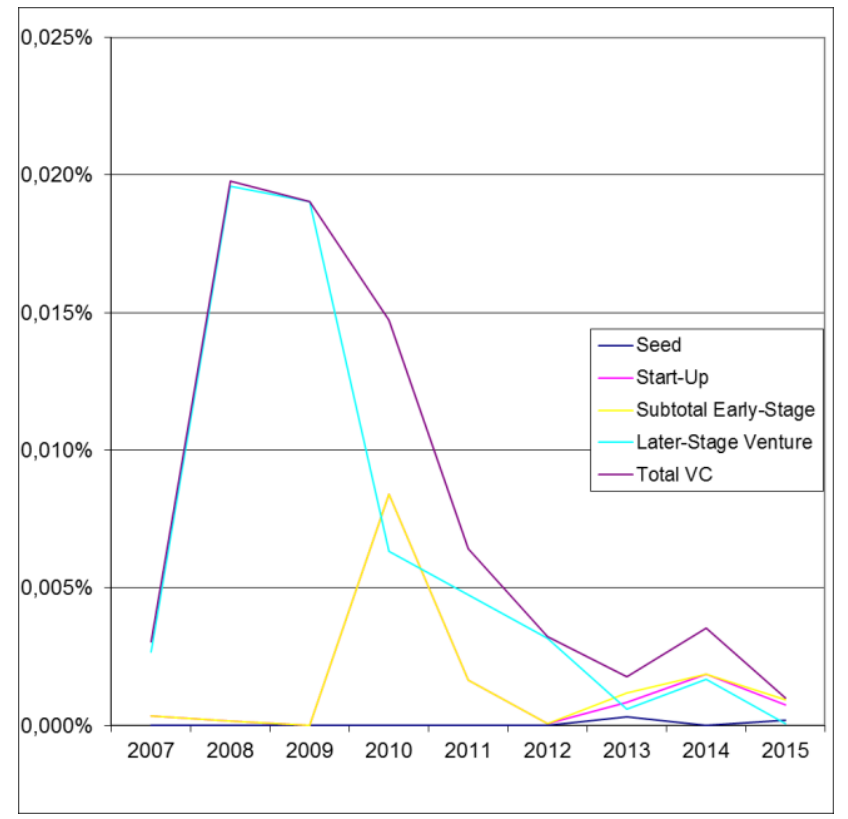

Data source: EVCA and Invest Europe, Eurostat

Chart 1. Investment amounts and number of portfolio companies in the Czech Republic, by venture capital stage, 2007-2015, \% of GDP 
This is not only the case of the Czech Republic. As we can see from Chart 2, the whole Central and Eastern European region was performing below European average in 2015, with the only exception of the Baltic states. The strongest countries were Finland, Switzerland, France followed by Ireland and the United Kingdom.

If we compare data on PE and VC investment activity in the Czech Republic with total European figures over the period of 2007-2013 as in Table 1, we find out that besides the overall weak performance of the market in the Czech Republic, there are also differences in particular categories. A clear investment gap can be observed in seed stage and start-up stages, with almost no activity in the Czech Republic (0,80\% share on total investment amount, $15 \%$ share on number of companies) but quite strong activity in Europe. However, these particular figures developed positively in the Czech Republic over 2014-2015, although we saw the total figures declining.

Significant difference prevails especially in the share on number of companies - whereas more companies in Europe received venture capital (61\%) than other private equity investments such as buyouts or growth financing (39\%), the Czech figures showed results vice versa: only $33 \%$ of companies received venture capital and $67 \%$ obtained other PE investment. The share of venture capital has increased by almost 5 p.p. over 2014-2015.

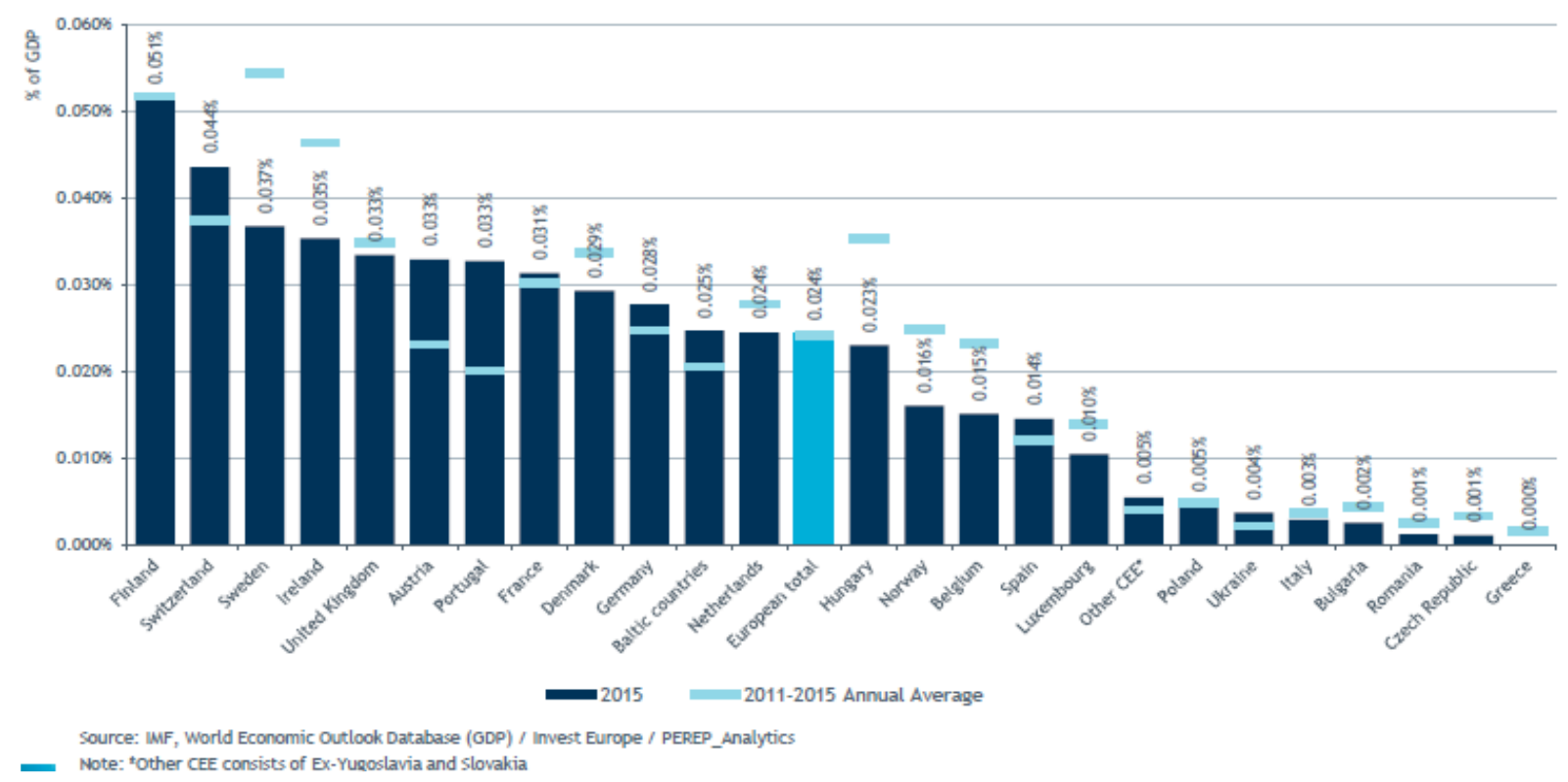

Source: Invest Europe

Chart 2. Venture Capital investment in $\mathbf{2 0 1 5}$ as GDP percentage by country of portfolio company (market statistics)

The cause of this situation is clear: Czech VC funds invest in larger projects than in the rest of Europe. Whereas average investment amount per company was EUR 2.0 million in Europe, it was EUR 3.6 million in the Czech Republic. A rapid increase has been observed in European figures over 20142015 - in 2007-2013, the average venture capital investment ticket was only EUR 1.3 mil.

Due to lack of market activity, the share of venture capital funding on GDP in the Czech Republic is significantly lower than in Europe. The following Chart 3 depicts investment value by venture capital stage to GDP ratio in the Czech Republic and European countries. 


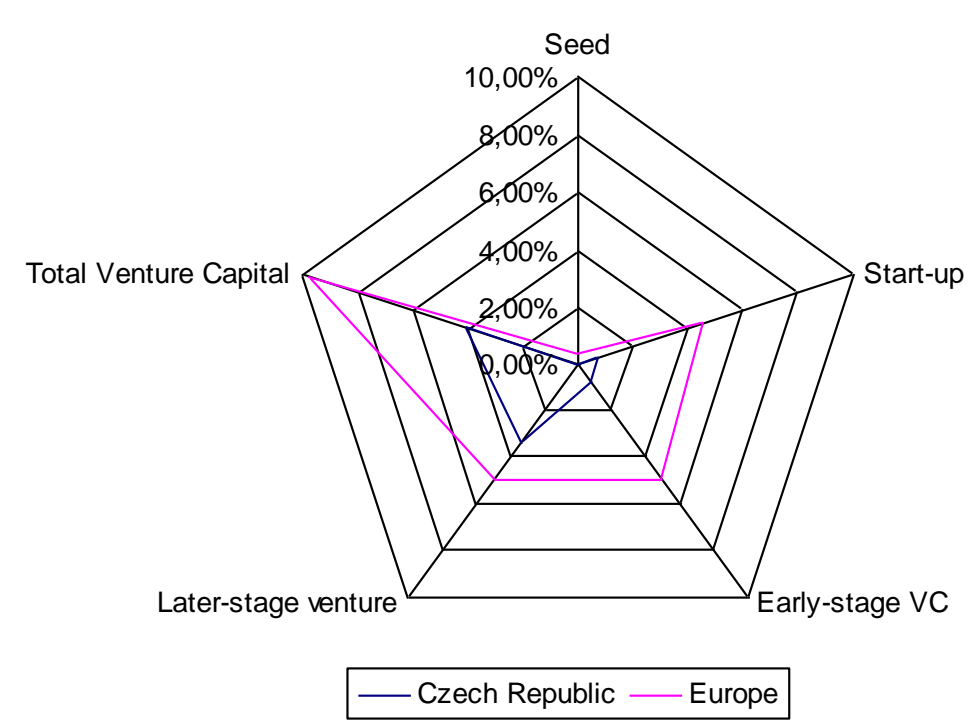

Source: Own adjustment of EVCA and Eurostat data

\section{Chart 3. Venture capital investments to GDP (current prices, EUR) percentage ratio ratio by stage, Czech Republic and Europe, 2007-2013 totals}

In general terms, early stage enterprises receive only a little venture capital in the Czech Republic. The legislation does not encourage PE investors enough to enter the venture capital market as well. This is particularly evident from the data on PE and VC funds investing in the Czech Republic (full CVCA members). Only a few of them are oriented on early stage investments and only one fund with total sources of EUR 36.4 million prefers also investments under EUR 1 million. The total amount of funds managed in the Czech Republic is about EUR 4.5 billion and the average fund size is EUR 373 million. On average, the minimum deal size is EUR 6.5 million and maximum EUR 50 million. Thus, seed, start-up and even smaller later-stage venture projects cannot fulfil the threshold of minimum investment values required by VC funds investing in the Czech Republic. This creates a burden for companies seeking equity financing of lesser values creating possible market inefficiency.

Furthermore, business angels' networks do not adequately take the place of lacking early stage venture capital funds due to CVCA findings. Ventures already having research and development results must still seek funds for their commercialization among friends and family or rely on bank loans and grants.

The reluctance towards capital-based instruments may stem from the pursuit of a high level of autonomy by the businesses. Both entrepreneurial candidates and representatives of companies in further phases of development indicated the need for independence as one of the main reasons for starting or having started their businesses according to a survey in Poland. Businesses also stress the lack of the competences of financial institutions and simplistic, underdeveloped and inappropriate approach to new business ventures' assessment in certain knowledge intensive industries, such as biotechnology. 


\section{Conclusion}

The paper has analyzed the development and compared Czech and European private equity and venture capital markets in 2007-2015 respectively, mainly to find out the differences in market development trends over 2014-2015.

In general terms, early stage enterprises receive only a little venture capital in the Czech Republic. Although some recent improvement has been observed, the environment including regulation requirements put on pension funds does not encourage $P E$ investors enough to enter the venture capital market as well. This is particularly evident from the data on PE and VC funds investing in the Czech Republic (full CVCA members). Only a few of them are oriented on early stage investments and only Credo Ventures II prefers also investments with ticket under EUR 1 million. Seed, start-up and even smaller later-stage venture projects cannot fulfil the threshold of minimum investment values required by vast majority of VC and PE funds active in the Czech Republic. This still creates a clear burden for companies seeking equity financing of lesser values creating possible market inefficiency.

Furthermore, business angels' networks do not adequately take the place of lacking early stage venture capital funds due to CVCA findings. Ventures already having research and development results must still seek funds for their commercialization among friends and family or rely on bank loans and grants.

The very surprising feature of the analysis was the complete downturn trend of both venture capital and private equity investing in the Czech Republic in 2015. The cause of this development will be analysed further in our coming research, as the Czech economy belongs to the fastest growing European countries and many new initiatives supporting start-ups have been put in place over the last few years.

\section{References}

[1] CVCA (2010). The Czech Republic 2009. Retrieved from http://www.cvca.cz.

[2] CVCA (2013). Czech Private Equity \& Venture Capital Association 2012 Activity Report. Retrieved from http://www.cvca.cz/.

[3] CVCA (2016). Dobrá kondice české ekonomiky svědčí i private equity transakcím, shodují se CVCA a Deloitte. CVCA press release in Czech. Retrieved from http://www.cvca.cz.

[4] ČNB (2016). Doporučení k řízení rizik spojených s poskytováním retailových úvěrů zajištěných rezidenční nemovitostí. Úřední sdělení České národní banky ze dne 14. června 2016. Věstník ČNB částka 6/2016 ze dne 14. června 2016. ČNB recommendation act for banks in Czech language.

[5] Dvořák I., Procházka P. (1998). Rizikový a rozvojový kapitál. Venture Capital. Prague: Management Press.

[6] EC (2006). Community Guidelines on State aid to promote risk capital investments in small and mediumsized enterprises. Official Journal of the European Union, 18 August 2006, C 194, p. 2-21.

[7] EVCA (2007). Guide on Private Equity and Venture Capital for Enterpreneurs. Retrieved from http://www.evca.eu.

[8] EVCA (2011). Central and Eastern Europe Statistics 2010. An EVCA Special Paper edited by the EVCA Central and Eastern Europe Task Force. Retrieved from http://www.evca.eu.

[9] EVCA (2013). Central and Eastern Europe Statistics 2012. An EVCA Special Paper edited by the EVCA Central and Eastern Europe Task Force. Retrieved from http://www.evca.eu.

[10] EVCA (2014). Central and Eastern Europe Statistics 2013. An EVCA Special Paper edited by the EVCA Central and Eastern Europe Task Force. Retrieved from http://www.evca.eu.

[11] EVCA (2014b). 2013 European Private Equity Activity. Statistics on Fundraising, Investments \& Divestments. Retrieved from http://www.evca.eu.

[12] EVCA (2015). Central and Eastern Europe Statistics 2014. An EVCA Special Paper edited by the EVCA Central and Eastern Europe Task Force. Retrieved from http://www.evca.eu.

[13] Invest Europe (2016). Central and Eastern European Private Equity Statistics 2015. Retrieved from http://www.investeurope.eu/. 
[14] IMF (2009). Balance of Payments and International Investment Position Manual. Sixth Edition (BPM6). Washington D.C.: International Monetary Fund.

[15] Martin M. (2013). The Barriers to Growth of Biotechnology Companies in Emerging Economies. Regional Case Study Analysis. In: International Journal of Economic Sciences, Vol. II (No. 1), p. 21-39.

[16] Matejun M. (2013). Instruments Supporting Development in the Life Cycle of Small and Medium-Sized Enterprises. In: International Journal of Economic Sciences, Vol. II (No. 1), p. 40-60.

[17] Merton R. C., Perold A. (1993) Theory of Risk Capital in Financial Firms. Journal of Applied Corporate Finance No. 6/1993, p. 16-36. https://doi.org/10.7312/chew14362-007.

[18] Pošta V. (2012). Time-Varying Risk Premium in the Czech Capital Market: Did the Market Experience a Structural Shock in 2008-2009? Finance a úvěr, No. 5/2012, p. 450-470.

[19] Ptáček (2014). Equity Gap on the Venture Capital Market in the Czech Republic. International Journal of Business and Management. Vol. II (No. 1), p. 59-75.

[20] Wright M., Robbie K. (1998). Venture Capital and Private Equity: A Review and Synthesis. Journal of Business Finance \& Accounting No. 25/1998, p. 521-570.

[21] Zinecker M., Rajchlová J. (2010). Private equity and venture capitalists investment criteria in the Czech Republic. Brno: Acta Universitatis Agriculturae et Silviculturae Mendelianae Brunensis, No. 6/2010, p. 2638. https://doi.org/10.11118/actaun201058060641. 